\title{
Adhesion of Dextran to Streptococcus mutans
}

\author{
By J. KELSTRUP AND T. D. FUNDER-NIELSEN \\ Department of Microbiology, The Royal Dental College, \\ DK-8000 Aarhus, Denmark
}

(Received 22 October 1973; revised I I November 1973)

\begin{abstract}
SUMMARY
Fifteen strains of Streptococcus mutans were agglutinated by 5 to $50 \mathrm{ng}$ Leuconostoc dextran $/ \mathrm{ml}$, and one by $500 \mathrm{ng} / \mathrm{ml}$. Competitive inhibition of the agglutination by sugars or sugar alcohols suggested that the spatial arrangement of the $\mathrm{HOC}(3) \mathrm{H}$ and $\mathrm{O}(\mathrm{I})$ groups were important in the dextran but that the dextran receptor is not identical with the dextran reactive site of glucosyl transferase. Periodate oxidation of the dextran, with or without subsequent borohydride reduction, prevented agglutination, again implicating the $\mathrm{C}_{3}$ group. Pretreatment of dextran with cyclohexyl-isocyanide or of $S$. mutans with $4.0 \mathrm{M}$-urea, 0.0I M-EDTA or $0.1 \%$ sodium dodecyl sulphate prevented agglutination; the last three reagents dispersed organisms already agglutinated. $\mathrm{Ca}^{2+}$ or $\mathrm{Mg}^{2+}$ reversed the effect of EDTA. Exposure of bacteria to $60^{\circ} \mathrm{C}$ or to papain for a few minutes impaired agglutination, so the dextran receptor site may be protein.
\end{abstract}

\section{INTRODUCTION}

The prime habitat of Streptococcus mutans is dental plaques, which are dense bacterial masses firmly adhering to the teeth and consisting of a variety of micro-organisms. S. mutans is able to synthesize from sucrose high-molecular-weight glucans which are of decisive importance in plaque formation (Gibbons \& Keyes, 1969); it synthesizes several types of glucan (Guggenheim \& Newbrun, 1969), differing in solubility and glucoside linkages and probably contributing to the plaque formation in different ways. The significance of $\alpha-\mathrm{I}, 3-$ linked glucans has been demonstrated in humans (Kelstrup \& Funder-Nielsen, 1973) as well as in an animal model (Guggenheim, Regolati \& Mühlemann, 1972), and the importance of $\alpha$-I,6-linked glucans has been shown in animals (review by Guggenheim et al. 1972).

The formation of dental plaque requires the cohesion of micro-organisms. Aggregation of polysaccharide-coated $S$. mutans has been demonstrated previously, and a description of the molecular interactions between the polysaccharides has been given (Kelstrup \& FunderNielsen, 1972). A different type of aggregation was observed by Gibbons \& Fitzgerald (I969), who found that the addition of even minute amounts of dextran to a suspension of glucose-grown $S$. mutans cells caused them to agglutinate, probably because several organisms adhered to the same dextran molecules. The phenomenon was not found in other bacterial species tested, and it was noted that of several polymers tested only dextran was capable of agglutinating $S$. mutans.

It was proposed that the adhesion of $S$. mutans to dextran, causing them to cohere, is an important feature in the colonization by this organism on the teeth. This paper reports some characteristics of the dextran receptors and of the bonds between bacteria and dextran. 


\section{METHODS \\ Bacteria and cultivation}

S. mutans strains Ingbritt, C67-I and c67-25 (Krasse, 1966; de Stoppelaar, König, Plasschaert \& van der Hoeven, I97I) as well as I4 freshly isolated human strains were used in this study. Strain $\mathrm{c} 67-25$, a mutant of $\mathrm{C} 67-\mathrm{I}$, is not agglutinated by dextran, even at a concentration of $10 \mathrm{mg}$ dextran $/ \mathrm{ml}$. The cultivation and harvesting conditions have been described previously (Kelstrup \& Funder-Nielsen, I972). After washing in $0 \cdot 145 \mathrm{M}-\mathrm{NaCl}$ they were lyophilized and kept in a desiccator over silica gel at atmospheric pressure.

\section{Agglutination procedure}

Bacteria were suspended in $0.02 \mathrm{M}$-phosphate buffer $\left(\mathrm{pH}_{7} \cdot 4\right.$ ) containing $0.10 \mathrm{M}-\mathrm{NaCl}$ and $0.00 \mathrm{I} \mathrm{M}-\mathrm{CaCl}_{2}$ (CaSP). Bacteria $(2.0 \mathrm{mg} / \mathrm{ml})$ were incubated with dextran for $60 \mathrm{~min}$ at $35{ }^{\circ} \mathrm{C}$ with a brief shaking every $\mathrm{I} 5 \mathrm{~min}$, and then examined visually and graded o (no agglutination) to $4+$ (marked agglutination). Strain Ingbritt, C67-I, or both, were incubated with $10 \mu \mathrm{g}$ dextran $/ \mathrm{ml}$ as a positive control and without dextran as a negative control, and strain $\mathrm{C}^{6} 7-25$ was usually incubated with $10 \mu \mathrm{g}$ dextran $/ \mathrm{ml}$ as a further control.

\section{Dextran}

Dextran 2000 (Pharmacia), with an average molecular weight of 2000000 , is synthesized by Leuconostoc mesenteroides strain B5I 2. It contains about $95 \% \alpha-\mathrm{I}, 6$ glucoside linkages (Lindberg \& Svensson, 1968) with side chains mostly of one or two glucose residues (Larm, Lindberg \& Svensson, 1971), indicating that it is a rather linear, extended and flexible molecule (Rees \& Scott, 197I). It was dissolved by heating in 0.0 I M-EDTA, dialysed against Ioo vol. 0.0 I M-EDTA at $4{ }^{\circ} \mathrm{C}$ for $24 \mathrm{~h}$ to remove contaminating divalent cations, and then dialysed for $24 \mathrm{~h}$ against water. A few $\mathrm{ml}$ of chloroform were added to the dialysis fluid to inhibit microbial growth; the chloroform was finally removed from the dextran solution by heating at $60{ }^{\circ} \mathrm{C}$ for $30 \mathrm{~min}$.

For some experiments the dextran was treated with various chemicals. A solution containing $40 \mu \mathrm{g}$ dextran $/ \mathrm{ml}$ was mixed with an equal volume of the compound to be tested and incubated at $35{ }^{\circ} \mathrm{C}$ for $60 \mathrm{~min}$. Irreversible effects were detected after subsequent removal of the compounds by dialysis for $48 \mathrm{~h}$ against two changes of $100 \mathrm{vol}$. of CaSP. Modification of the dextran by periodate oxidation with or without borohydride reduction was accomplished according to Akher, Hamilton, Montgomery \& Smith (I952).

\section{Treatment of bacteria}

(i) Heat treatment. Bacteria were suspended in CaSP at $4.0 \mathrm{mg} / \mathrm{ml}$, heated at the desired temperature for Io min, and immediately cooled in water at room temperature.

(ii) Chemical treatment. Bacteria were suspended at $\mathrm{I} \cdot 0 \mathrm{mg} / \mathrm{ml}$ in a solution of the compound to be tested, shaken vigorously for $10 \mathrm{~s}$, sedimented at $5000 \mathrm{~g}$ for $15 \mathrm{~min}$, washed and centrifuged twice, and resuspended in CaSP.

(iii) Papain. Suspensions ( $8.0 \mathrm{mg}$ bacteria/ml in $0.067 \mathrm{M}$-phosphate buffer, $\mathrm{pH} 7.5$ ) and enzyme solution $(20 \mu \mathrm{g} / \mathrm{ml}$ in $0.067 \mathrm{M}$-phosphate buffer, $\mathrm{pH} 7.5$, containing $0.002 \mathrm{M}$-EDTA and $0.0 \mathrm{I} \mathrm{M}$-cysteine- $\mathrm{HCl}$ ) were preheated, mixed in equal volumes, and incubated at $35{ }^{\circ} \mathrm{C}$. At various times the papain digestion was stopped by diluting samples of the mixture ten times in ice-cold $0.1 \%$ egg albumin. The organisms were sedimented at $5000 \mathrm{~g}$ for $15 \mathrm{~min}$, washed and centrifuged three times, and resuspended in CaSP. Control experiments indicated that egg albumin alone did not affect subsequent agglutination. 


\section{RESULTS \\ Agglutination}

All strains of $S$. mutans tested, except the mutant strain $c 67-25$, were agglutinated by dextran. Fifteen strains required 5 to $50 \mathrm{ng}$ dextran $/ \mathrm{ml}$, while one required $500 \mathrm{ng} / \mathrm{ml}$ for agglutination. Strains Ingbritt and C67-I both required $10 \mathrm{ng} / \mathrm{ml}$. The amounts of dextran needed were of the same order of magnitude as reported earlier (Gibbons \& Fitzgerald, 1969). Freshly isolated strains did not differ from strains kept in the laboratory for a long time. The different dextran requirements of the strains tested may reflect differences in the numbers of receptor sites. Periodate oxidation with or without subsequent borohydride reduction made the dextran incapable of agglutinating $S$. mutans cells.

\section{Competitive inhibition of agglutination by sugars and sugar alcohols}

The compound to be tested $(500 \mathrm{mg} / \mathrm{ml})$ was incubated with strain Ingbritt $(5.0 \mathrm{mg} / \mathrm{ml})$ at $35^{\circ} \mathrm{C}$ for $30 \mathrm{~min}$ before adding Io $\mu \mathrm{g}$ dextran $/ \mathrm{ml}$. This high concentration of test compounds was chosen to avoid false negative results (Gibbons \& Fitzgerald, 1969). Ethylene glycol, 3-O-methyl glucoside, maltose, or cellobiose $(60 \mathrm{mg} / \mathrm{ml})$ did not inhibit agglutination, but glycerol, erythritol, arabitol, arabinose, sorbitol, glucose, 2-deoxyribose, fructose, mannose or galactose did. $\alpha$-Methyl glucoside markedly impaired but did not completely inhibit agglutination. The final $\mathrm{pH}$ was never below $6 \cdot 5$, indicating that the effect was not due to increased hydrogen ion concentration.

\section{Elimination of agglutination by dissociative agents}

Strains Ingbritt and $\mathrm{C67}$-I were tested with $75 \mathrm{ng}$ dextran/ml. Urea (4 M), 0.0 I M-EDTA or $0 . \mathrm{I} \%$ sodium dodecyl sulphate eliminated agglutination, while $\mathrm{I} \cdot 0 \%$ Tween $80, \mathrm{I} \cdot 0 \%$ sodium deoxycholate, saturation with cyclohexyl-isocyanide, $2 \cdot 0 \mathrm{M}$-urea, or $\mathrm{I} \cdot 5 \mathrm{M}-\mathrm{NaCl}$ had no effect.

\section{Prevention of agglutination by treatment of dextran}

The potent hydrogen-bond-forming agent cyclohexyl-isocyanide abolished the agglutinating capability of dextran but treatment with and subsequent removal of $\mathrm{I} \cdot 0 \%$ Tween 80 , $\mathrm{I} \cdot 0 \%$ sodium deoxycholate, $4.0 \mathrm{M}$-urea, $\mathrm{I} \cdot 5 \mathrm{M}-\mathrm{NaCl}$ or $\mathrm{I} \cdot 0 \%$ sodium dodecyl sulphate did not.

\section{Effects of treatment of bacteria}

Pretreatment of strains Ingbritt or C67-I with 4.0 M-urea, 0.0 I M-EDTA or $0.1 \%$ sodium dodecyl sulphate made the bacteria unable to agglutinate, explaining the previously noted dissociation of agglutinated bacteria-dextran mixtures. Treatment with $\mathrm{I} \cdot 0 \%$ Tween 80 , $1 \cdot 0 \%$ sodium deoxycholate, saturated cyclohexyl-isocyanide, $2 \cdot 0 \mathrm{M}$-urea or $\mathrm{I} \cdot 5 \mathrm{M}-\mathrm{NaCl}$ did not affect subsequent agglutination. Heating at $60^{\circ} \mathrm{C}$ diminished, and at $100{ }^{\circ} \mathrm{C}$ prevented, subsequent agglutination. Papain treatment impaired agglutination after only a few minutes and completely abolished it within I h.

\section{Cation requirement}

Portions of EDTA-treated bacteria were mixed with $10 \mu \mathrm{g}$ dextran $/ \mathrm{ml}$ and various cations were added. $\mathrm{Ca}^{2+}$ or $\mathrm{Mg}^{2+}$ ions $\left(\mathrm{IO}^{-5} \mathrm{M}\right.$ ) partially restored agglutination, $1 \mathrm{O}^{-3} \mathrm{M}$ fully restored it. $\mathrm{Ba}^{2+}, \mathrm{Li}^{+}, \mathrm{Na}^{+}$or $\mathrm{K}^{+}$did not. 


\section{DISCUSSION}

Topography of the receptor sites. Modifying the dextran, either by periodate oxidation or by this procedure followed by borohydride reduction, made it incapable of agglutinating the bacteria. Since these treatments remove $\mathrm{C}_{3}$ and form aldehyde or alcohol groups at $\mathrm{C}_{2}$ and $\mathrm{C}_{4}$, while $\mathrm{Cr}, \mathrm{C}_{5}$ and $\mathrm{C} 6$, or the adjoining atoms, are not altered, this observation suggests that one or more atoms in the region of $\mathrm{C}_{2}, \mathrm{C}_{3}$ or $\mathrm{C}_{4}$ are of significance. The finding that mannose and galactose were both effective in blocking dextran agglutination appeared to rule out $\mathrm{C}_{2}$ and $\mathrm{C}_{4}$, leaving the atoms at $\mathrm{C}_{3}$ as a possibility. This seems to be corroborated by the observation that $3-O$-methyl glucoside did not block dextran agglutination, indicating that this modification of the glucose molecule prevents a fit at the receptor site. Furthermore, the limited block by $\alpha$-methyl glucoside suggests that the atoms around $\mathrm{CI}_{\mathrm{I}}$ are involved.

Fructose blocked agglutination, and molecular models suggest that $\mathrm{HOC}(3) \mathrm{H}$ and $\mathrm{O}(\mathrm{I})$ of $\beta$-fructofuranoside as well as $\beta$-pyranoside may assume a spatial arrangement resembling that of $\alpha$-glucopyranoside. This is true also for $\beta$-arabinose in the furanose, but not the pyranose, form, and for 2-deoxyribose, possibly explaining why these sugars inhibit agglutination. The finding that maltose and cellobiose did not significantly block dextran agglutination may be explained in terms of steric hindrance.

$\mathrm{HOC}(3) \mathrm{H}$ and $\mathrm{O}(\mathrm{I})$ of dextran may therefore be essential for adhesion to receptors on the surface of $S$. mutans, and the receptors may mirror this configuration. The consequence that ethylene glycol would be unable to inhibit the reaction while sugar alcohols with three or more carbon atoms could do so was confirmed; their configuration would then resemble that suggested by Sundaralingam (1972).

The high concentration of blocking agents needed to inhibit agglutination is likely to reflect the large number of dextran receptor sites: approximately $10^{5} /$ organism (R. J. Gibbons, personal communication).

Non-identity of surface dextran receptors and glucosyl transferase. Gibbons \& Fitzgerald (I969) mentioned the possibility that the surface dextran receptors of $S$. mutans might be identical with the dextran reactive sites of the glucan-synthesizing enzyme, glucosyl transferase. The present findings appear not to support this view. In addition to dextran a number of carbohydrates, including maltose, may serve as glucosyl acceptors and influence the enzyme reaction (Gibbons \& Nygaard, 1968). Maltose, however, even at high concentrations, did not block dextran agglutination, suggesting that glucosyl transferase and surface dextran receptors are separate entities.

Nature of the receptor sites. The inactivation of the receptors by papain and heat suggests protein moieties at the receptor sites. The experiments do not reveal whether the receptors per se or the structures supporting them are affected, but the strikingly rapid effect of papain may imply that an essential part of the receptor is protein.

This assumption is corroborated by the irreversible destruction of the receptors by the protein denaturants sodium dodecyl sulphate and urea. Urea-mediated dispersion of flocs of polysaccharide-coated $S$. mutans cells was reversible (Kelstrup \& Funder-Nielsen, 1972), indicating that destruction of dextran receptors is not involved in this disaggregation.

Calcium or magnesium ions were required for agglutination of $S$. mutans. Although it has been impossible to determine whether these ions were needed for the formation of receptordextran bonds or for maintenance of the receptors, the latter appears more probable. Leuconostoc dextran is not known to contain appreciable numbers of negatively charged groups that would allow cation bridges to be formed, and furthermore a number of simple sugars and sugar alcohols displayed an affinity for the receptors. 
The receptor-dextran bonds. Cyclohexyl-isocyanide presumably abolished agglutination because the isocyanide formed hydrogen bonds with the available hydroxyl groups of the dextran, thereby preventing them from reacting to form hydrogen bonds with the receptors. Only sodium dodecyl sulphate or strong urea dispersed agglutinated bacteria. The dispersion was probably caused by destruction of the receptors rather than dissociation of the receptordextran bonds. The fact that cyclohexyl-isocyanide did not eliminate agglutination suggests that the bonds between organisms and dextran are energetically favourable, but may in part be due to steric hindrances.

Other types of linkages than hydrogen bonds could not be detected. Neither sodium chloride nor the ionic detergent sodium deoxycholate had any effect, even at relatively high concentrations, suggesting that coulombic forces are not significant. Moreover, since the non-ionic surface active agent Tween 80 did not reduce agglutination one may assume that hydrophobic areas of the bacterial surface are not involved in the adhesion of dextran to S. mutans.

The valuable suggestions of $C$. Nolde are much appreciated. The investigation was supported in part by the Jubilaeumsfond of F. L. Smidth \& Co. A/S, and by the Danish Medical Research Council (grant 5I2-I689).

\section{REFERENCES}

Akher, M., Hamilton, J. K., Montgomery, R. \& SMith, F. (I952). A new procedure for the determination of the fine structure of polysaccharides. Journal of the American Chemical Society 74, 4970-4971.

Gibbons, R. J. \& FitzGerald, R. J. (1969). Dextran-induced agglutination of Streptococcus mutans, and its potential role in the formation of microbial dental plaques. Journal of Bacteriology 98, 341-346.

GibBons, R. J. \& KEYEs, P. H. (1969). Inhibition of insoluble dextran synthesis, plaque formation and dental caries in hamsters by low molecular weight dextran. Archives of Oral Biology 14, 72 I-724.

GibBons, R. J. \& NyGAaRd, M. (I968). Synthesis of insoluble dextran and its significance in the formation of gelatinous deposits by plaque-forming streptococci. Archives of Oral Biology 13, I249-1262.

GuGGeNHerm, B. \& NEWBRUN, E. (1969). Extracellular glucosyltransferase activity of an HS strain of Streptococcus mutans. Helvetica odontologica acta $\times 3,84-97$.

Guggenheim, B., Regolati, B. \& MühlemanN, H. R. (1972). Caries and plaque inhibition by mutanase in rats. Caries Research 6, 289-297.

KeLSTRUP, J. \& FUNDER-NIELSEN, T. D. (1972). Molecular interactions between the extracellular polysaccharides of Streptococcus mutans. Archives of Oral Biology 17, I659-1670.

KELSTRUP, J. \& FundER-NielSEN, T. D. (1973). Enzymatic reduction of the colonization of Streptococcus mutans in human dental plaque. Acta odontologica scandinavica 3r, 249-253.

KraSSE, B. (1966). Human streptococci and experimental caries in hamsters. Archives of Oral Biology II, 429-436.

LARM, O., LindBerG, B. \& Svensson, S. (I97I). Studies on the length of the side chains of the dextran elaborated by Leuconostoc mesenteroides. Carbohydrate Research 20, 39-48.

LINDBerg, B. \& Svensson, S. (1968). Structural studies of dextran from Leuconostoc mesenteroides NRRL B-512. Acta chemica scandinavica 22, I907-I912.

Rees, D. A. \& ScotT, W. E. (1971). Polysaccharide conformation. VI. Journal of the Chemical Society B, 469-479.

de Stoppelaar, J. D., König, K. G., Plasschaert, A. J. M. \& van der Hoeven, J. S. (1971). Decreased cariogenicity of a mutant of Streptococcus mutans. Archives of Oral Biology 16, 971-975.

Sundaralingam, M. (1972). Molecular structures and conformations of the phospholipids and sphingomyelins. Annals of the New York Academy of Sciences 195, 324-355. 